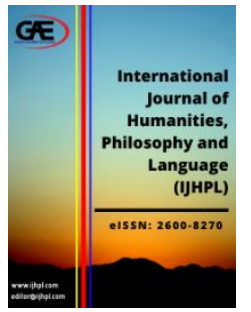

\author{
INTERNATIONAL JOURNAL OF \\ HUMANITIES, PHILOSOPHY \\ AND LANGUAGE \\ (IJHPL) \\ www.ijhpl.com
}

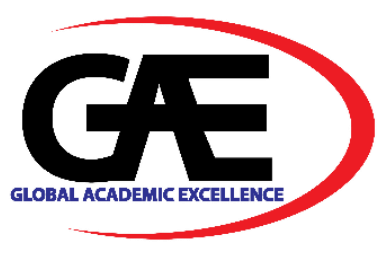

\title{
THE ARAB SPRING ONLINE NEWS COVERAGE: CORPUS- BASED ANALYSIS OF THE TUNISIAN AND EGYPTIAN REVOLUTION KEYWORDS
}

\author{
Muhammad Marwan Ismail ${ }^{1 *}$, Farah Nadia Harun ${ }^{2}$, Wan Moharani Muhamad ${ }^{3}$, Nurhasma Muhamad
} $\mathrm{Saad}^{4} \&$ Zulkipli Md Isa

1 Faculty of Major Languages, Universiti Sains Islam Malaysia, Malaysia

Email: marwanismail@usim.edu.my

2 Department of Modern Languages, University of Birmingham, UK

Email: fbh498@bham.ac.uk

$3 \quad$ Faculty of Major Languages, Universiti Sains Islam Malaysia, Malaysia

Email: moharani@usim.edu.my

4 Faculty of Major Languages, Universiti Sains Islam Malaysia, Malaysia

Email: nurhasma@usim.edu.my

5 Faculty of Major Languages, Universiti Sains Islam Malaysia, Malaysia

Email: zulkipli@usim.edu.my

Corresponding Author

\section{Article Info:}

Article history:

Received date: 10.03.2021

Revised date: 08.04.2021

Accepted date: 11.05.2021

Published date: 15.06.2021

\section{To cite this document:}

Ismail, M. M., Harun, F. N., Muhamad, W. M., Saad, N. M., \& Md Isa, Z. (2021). The Arab Spring Online News Coverage: CorpusBased Analysis Of The Tunisian And Egyptian Revolution Keywords. International Journal of Humanities, Philosophy and Language, 4 (14), 5270.

\section{Abstract:}

In 2011, the Arab world had become the centre of attention once again after the emergence of the so-called 'Arab Spring' in December 2010. This historical event in the modern history of the Arab region has brought significant social and political reform to the Arab world. The wave of Arab uprising begins in Tunisia at the end of 2010, rapidly separated into other neighbouring countries such as Egypt, Libya, Morocco, Syria, Bahrain, and Sudan. Since the early stage of protest, which mainly participated by locals, mass media has comprehensively reported this historical event, which brought down many Arab leaders in power for decades. Thus, Arab Spring has become the headline of many international media outlets, and the media are still discussing the significant impact of the event until now. Hence, the main objective of the study is to examine the event's Arabic online news discourse by focusing on the keywords and prominent social actors in the news reports surrounding the Arab Spring. This will indicate what has been included and excluded or highlighted and marginalised in the news coverage. The data is consist of Modern Standard Arabic (MSA) online news published by four prominent news outlets namely with different origin and background: Al-Arabia of Saudi Arabia, Al-Jazeera of Qatar, BBC Arabic of the UK and CNN of the USA.

These well-established news outlets were selected for their comprehensive Copyright @ GLOBAL ACADEMIC EXCELLENCE (M) SDN BHD - All rights reserved 
Volume 4 Issue 14 (June 2021) PP. 52-70

DOI 10.35631/IJHPL.414004

DOI: $10.35631 /$ IJHPL.414004.

This work is licensed under CC BY 4.0

(a) international coverage aims at various Arabic readers worldwide. The study employs corpus linguistics analytical tools by using corpus data mining software 'AntConc 3.4'. Then, the quantitative results of corpus data will be analysed using a qualitative approach based on the textual-oriented Critical Discourse Analysis (CDA) of Fairclough (1992) and Wodak (2001). The result shows that news coverage of the event has highlighted several keywords that indicate the main social actors and main social events of the Arab Spring. These keywords are the shared command features among the news outlets, although each outlet portraying them is significantly different. Finally, the article presents suggestions for other related studies in the future.

Keywords:

Arab Spring, Arabic Online News, CDA, Corpus Linguistics, Keywords

\section{Introduction}

After ten years of the so-called 'Arab Spring' (in Arabic الربيع العربيal-Rabi' al-Araby), people still talk about the event which massively changes the political and social landscape of the Arab world. The Arab Spring term does not emerge during the uprising. It was later on after the wave of Revolution hit many Arab countries, the term started to be used by the mass media and become a command term which widely being used to refer to the revolutionary wave of antigovernment demonstrations, protests and riots that happened in many Arab countries at the end of 2010 up until 2013. This up-scaled of protests against their Arab leaders who roled the countries for decades autocratically started on $18^{\text {th }}$ December 2010 in a remote area of Tunisia known as Sidi Bouzid. This small town of Tunisia located approximately $250 \mathrm{~km}$ south of the capital city of Tunis. The small protest participated by the locals than turned into a massive demonstration and reached Tunis city more than a week later with the help of the internet and social media. Local media, which heavily controlled by Ben Ali's regime, silence the event. The Tunisian's version of Arab Spring, also known as the 'Jasmine Revolution', has successfully brought down President Ben Ali, who governed Tunisia, from 1987 until he was forced to left Tunisia on 14th January 2011. The 'domino effect' of the Tunisian Jasmine Revolution then influenced other Arabs in the Middle East and North Africa (MENA) region to start their anti-government uprising. Egypt was the second Arab country to be hit by the wave of the Arab uprising, which successfully brought down President Mubarak (governed from 1981 - 2011). Hence, the so-called 'Arab Spring' had brought massive political changes in many Arab countries such as Tunisia, Egypt, Libya, Yemen, Syria, Bahrain, Morocco and Sudan.

As of 2014, three years after the first wave of the so-called 'Arab Spring' started in Tunisia, the Arab rulers from Tunisia, Egypt, Libya, and Yemen have been forced to step down after decades of clinging to power. Besides, big-scaled demonstrations, which resulted in political changes, have been reported in other Arab countries such as Algeria, Morocco, Iraq, Jordan, and Sudan. Even the Arabian Gulf, where most of the oil-rich Arab countries are located, were not exempted from being hit by the 'Arab Spring' wave. As a result, Bahrain, Oman, Kuwait and Saudi Arabia, for instance, are not excluded from recording a series of protests demanding changes in political and social issues. However, the Arabian Gulf protests were not as massive as those in other Arab countries.

The condition in Syria, the worst Arab country hit by the 'Arab Spring', is much worse and torn the country apart. The anti-government protests in Syria had turned into full-scale civil wars 


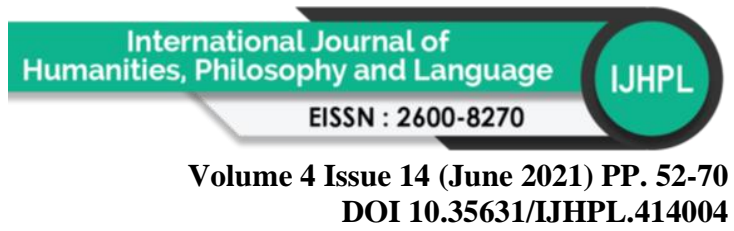

that involved many groups and sects and resulted in a more complex political crisis. Although the civil war has mostly stopped now, the country has torn apart, and it is doubtful that Syria will soon return to its pre-crisis state. The Syrian crisis has already claimed thousands of lives, and a hundred thousand more leave Syria and become refugees in many countries, particularly in Europe.

The significant of 'Arab Spring' as one of the significant historical events in the modern history of the Arab region has attracted international attention. Since $18^{\text {th }}$ December 2010, a day after Bouazizi set fire on himself as an act of protest that inspired the 'Arab Spring' wave, the mass media has provided comprehensive media coverage of the 'Arab Spring' events. The news on the Arab Spring increased dramatically when the 'domino effect' of Arab Spring spread widely, affecting many Arab countries from Northern Africa to the Arabian Gulf, from Morocco in the West to Bahrain in the East. Moreover, other non-Arab countries (in Africa and South America) have tried to initiate the same wave of uprising in their country, aiming to change the country's political structure. However, not many success stories have been heard from these attempts.

Several factors caused this historical Revolution which successfully removed many Arab dictators. The major factors that caused Arab Spring are the feeling of dissatisfaction with the governments and the vast gaps between the rich and the poor, in which the ruler's families monopolised the country wealth. This is happened in many Arab countries, particularly in Tunisia and Egypt. Moreover, factors that turned the protests participated by a small group of locals into nationwide demonstrations participated by millions of people are issues related to dictatorship among the Arab rulers, corruption, power abuse, human rights violations, unemployment, extreme poverty, and youth issues.

Thus, it is vital to examine the discursive constructions surrounding the so-called 'Arab Spring' in modern standard Arabic (MSA) news articles from prominent Arabic international news institutions. The mass media, particularly the modern standard Arabic online news providers, have reported every detailed about Arab Spring since the beginning of the event in Tunisia. However, these news coverage are differing from each news institution as each of them covered the event from a different point of views. As a result, these various versions of news reporting of the same event of the Arab Spring. Make the news report appear to be reporting on the different events, participated by different characters of social actors, or perhaps participated in different social events. There are keywords have been highlighted and emphasised in the news coverage, while other has been excluded and marginalised because it does not meet the outlets' criteria of 'newsworthy'. Therefore, it is fascinating to linguistically examine the discourses of Arab Spring in the modern standard Arabic online news by using a textual oriented Critical Discourse Analysis (CDA) approach with the assist of corpus linguistics analytical tools.

\section{Literature Review}

Previous studies have examined the use of mass media as a means of encouraging political participation. One of these studies, McLeod et al. (1999), studied mass media's role in political participation. The result argued that the newspaper readership received a substantial impact on institutionalised participation. Moreover, the result of the study showed that television news did not directly affect political participation. However, the news had a slightly indirect effect on the institutionalised participation. Despite that, the study emphasised that communication and mass media played an essential role in triggering local political participation. Eilders (2000), on the other hand, examined the role of media in German from 1994 to 1998 as political 


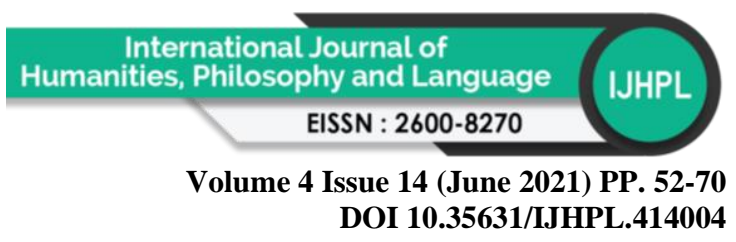

tools. The study suggested that by focusing and emphasising specific issues, the media outlets indicate their political stand to the audience and highlight the outlets' distinct ideological profile. The study's result is backed by another study, Mutz (2001), who critically examined the role of media in facilitating communication across political difference.

Showing that political institutions have used the media to serve their ideas. Schudson (2002) and Leeson (2008) examined how the news media can be utilised as political institutions. The study argued that political science has tended to overlook investigating the news media as political institutions, although there are many party-owned newspapers and throughout history an increasing "medialisation" of politics. In a more recent study, Howard and Parks (2012) analysed the role of social media in political change. The study suggested a working definition of social media and discussed other related term proposed by the concerned scholars in their studies. The study results indicate that social media consists of the information tools used to produce and distribute content.

Focusing on the Arab world, the Arabic media plays a vital role in the democratisation and political change in the Arab region of the Middle East and Nothern Africa (Lahlali, 2011, Ismail, 2019). This can be traced back to the 1950s with the emergence of Arabic unity discourse and Arab national identity, which being further enhanced in the 1990s with the start of the Arab transnational television broadcasting (Aldawood, 2004; Amin, 2001; Sakr, 2007, Lahlali, 2011). Many past studies have highlighted the features of Arabic transnational media outlets by focusing on bias and independence of various media institutions (Zayani \& Ayish, 2006; Miladi, 2006; Fandy, 2007; Volkmer, 2008; Mellor, 2011, Ismail et al., 2018, Ismail, 2019, Harun et al., 2019, Harun et al., 2020, Ismail and Harun, 2021). Despite the claim of impartial, independence, objectivity, and privately-owned, these Arabic media outlets have been used as political tools and controlled by people close to the government (Ismail et al., 2018, Ismail, 2019, Harun et al., 2019).

Thus, Arabic global media is associated directly or indirectly with specific agendas and ideologies. Moreover, these ideologies are rooted in regional conflicts within the Arab world (Fandy, 2007). Mellor (2011) tracked how Arab media outlets managed to move from working under the firm governmental grip to become commercially oriented media institutions but still cannot avoid governmental influence. Hence, there is little room for criticising these governments, compassionate national and international issues. On the positive side, the Arabic global media like Aljazeera, Al-Arabia, Al-Hurra, BBC Arabic and CNN Arabic have offered the Arab audiences a variety choice of content and presentation (Elareshi \& Gunter, 2010; AlJaber \& Gunter, 2013, Ismail et al., 2018, Ismail and Harun, 2021). As a result, these media outlets have created a challenge to the dominant Arabic state media. Besides, the Arabic international media promoted the freedom of expression through their discussions and current affairs programmes (Miladi, 2006, Harun et al., 2019, Harun et al., 2020), making them a more popular choice new generation of Arab audiences.

\section{Methodology}

The study has gathered a collection of modern standard Arabic (MSA) online news articles surrounding the Arab Spring, particularly those covering the Tunisian and the Egyptian Revolution. These two revolutions are the most vital version of the Arab Spring as it happened almost continuously after the fall of Ben Ali's regime in Tunisia and the Egyptian started to overthrow the then President of Mubarak. Although the two revolutions in Tunisia and Egypt 
shared many similarities and closely related to each other, each has unique features and factors that make each of the Revolution distinguished differ from others. Secondly, these two revolutions received the most coverage by the media, notably the Egyptian Revolution. Thirdly, it happened at the early stage of the Arab Spring, in which many were still underestimating the significant impact of the Revolution in bringing political reform to the region. Hence, many news institutions and many Western superpowers were yet to decide their apparent stance on the conflict. Many have yet to change their support during this stage and choose to stick with the old stance or playing safe by supporting both sides of the conflict. These online newspaper articles come from various prominent modern standard Arabic news outlets, representing the different background of each news institution's historical, social, political, and economic backgrounds. These modern Arabic news institutions are Al-Arabia of Saudi Arabia, AlJazeera of Qatar, BBC Arabic of the UK (Arab region office in Cairo) and CNN of the USA (Arab region office in Dubai). Moreover, Al-Arabia of Saudi Arabia and Al-Jazeera of Qatar represent the Arab international media as both are based in the Arab countries. In contrast, the BBC Arabic and CNN Arabic represent the 'West(ern)' media as both are the Arabic arm of the well-known media giant of the BBC and CNN in Britain and the United States of America.

As the Tunisian and Egyptian Revolution are uniquely different from each other while still many similarities, the news articles related to each of the Revolution also has been collected to maintain this feature. The two revolutions started at a different date as the Tunisian version started first and inspired the Egyptian to start their Revolution. Hence, the news articles pertaining to the Jasmine Revolution of Tunisia published between $17^{\text {th }}$ December 2010 (which marks the start of the Tunisian Revolution after Bouazizi set fire on himself) until $10^{\text {th }}$ March 2011, the temporary government of Tunisia takes charge of governing Tunisia after the Revolution. The details on the collection of these news articles are as follow:

\begin{tabular}{|l|l|l|l|l|}
\hline No. & Institution & Number of Articles & Total Words & $\%$ \\
\hline 1 & Al-Jazeera & 90 & 39,297 & 56.60 \\
\hline 2 & BBC Arabic & 40 & 21,790 & 25.16 \\
\hline 3 & Al-Arabia & 29 & 12,244 & 18.24 \\
\hline & TOTAL & 159 & 73,331 & 100 \\
\hline
\end{tabular}

Table 1: The Description Of Sub-Corpus Data For The Tunisian Revolution

On the other hand, the data of the Egyptian Revolution. ${ }^{1}$ Come from the collection of MSA only news articles dated $25^{\text {th }}$ January 2011, when the Egyptians start their mass protest in Tahrir Square during the national holiday of the Egyptian Police Day up until early May 2011 when the Egyptian Army takes charge of governing the country. The details on newspaper articles on the Egyptian Revolution are as follow:

\footnotetext{
${ }^{1}$ It is worth noting that, these dates $(25 / 1 / 2011-15 / 5 / 2011)$, the outlets also produced news about the Tunisian Revolution, which already reached a new milestone after Ben Ali's fall regime. However, the centre of attention was given by the media was on the then-ongoing uprising in Egypt. Hence, all the online news articles at these dates were treated within the Egyptian Revolution. Copyright $\odot$ GLOBAL ACADEMIC EXCELLENCE (M) SDN BHD - All rights reserved
} 
Volume 4 Issue 14 (June 2021) PP. 52-70 DOI 10.35631/LJHPL.414004

\begin{tabular}{|l|l|l|l|l|}
\hline No. & Institution & Number of Articles & Total Words & $\%$ \\
\hline 1 & BBC Arabic & 190 & 129,194 & 47.62 \\
\hline 2 & Al-Jazeera & 151 & 75,447 & 37.84 \\
\hline 3 & CNN Arabic & 43 & 20,731 & 10.78 \\
\hline 4 & Al-Arabia & 15 & 6,804 & 3.76 \\
\hline & TOTAL & 399 & 232,176 & 100 \\
\hline
\end{tabular}

Table 2: The Description of Sub-corpus Data for the Egyptian Revolution

In the next step, all these online news articles have been converted into electronic texts to collect corpus data for language analysis. This corpus contains 558 total number of articles which carry 305,507 total number words. These online news articles are dated $17^{\text {th }}$ December 2010 until $15^{\text {th }}$ May 2011, which covered the most crucial stage of the 2011 uprising in Tunisia and Egypt. The corpus was then analysed using corpus analysis software known as AntConc Software version 3.4.4.0 (w) date $20^{\text {th }}$ October 2014. This software is developed by Laurence Anthony from Waseda University, Japan. The software works well with Arabic texts and Arabic characters written from right to left.

The primary purpose of utilising corpus analysis software is to obtain useful qualitative data of keywords and wordlist in the corpus data. These quantitative data are extremely helpful for the online news articles' quantitative insights, particularly in exploring the significance of highlighting specific keywords and their impression of meaning. In addition, it will also uncover certain keyword which has been dropped from the news coverage of the event. Hence, indicated that the outlet has marginalised the significant of the keyword. Moreover, the comparison between keywords in each revolution of Tunisia and Egypt highlights the unique characteristics of each revolution even though it happens co-currently and closely related to each other within the mass wave of 'the Arab awakening'.

\section{Analysis of Results and Discussion}

This study's analysis results are focused on the wordlist and concordance analysis of social actors (one social actor for each Revolution: Ben Ali for Tunisia and Mubarak for Egypt). Hence, the study will first present the world list's analysis results beginning from the wordlist result surrounding the Tunisian Revolution before moving into the Egyptian Revolution. The discussion then compared the findings between the two revolutions by emphasising the similarities and differences. The corpus data analysis results and its discussion are as followed:

\section{Wordlist Results on Tunisian Revolution}

From the wordlist results produced by AntConc software, we can point out 13 critical keywords with the highest hit in word frequency. Furthermore, these 13 keywords also come in different forms associated with every single of them, such as verb, noun, adjective, singular and plural. All these make the hit numbers being increased. These keywords are:

\begin{tabular}{|l|l|l|l|}
\hline No. & Keyword & Hit & Note \\
\hline 1 & بن علي & 857 & Former Tunisian President. \\
\hline 2 & البو عزيزي الغني & 159 & The young man who sparks the Revolution. \\
\hline 3 & 157 & Most prominent Tunisian opposition leader. \\
\hline 4 & 151 & The Protests \\
\hline 5 & 104 & The Demonstrators \\
\hline
\end{tabular}




\begin{tabular}{|c|c|c|c|}
\hline 6 & الشعب & 98 & People \\
\hline 7 & الثورة & 94 & Revolution \\
\hline 8 & السلطات & 93 & The Authorities \\
\hline 9 & البطالة & 85 & Unemployment \\
\hline 10 & العنف & 71 & Violence \\
\hline 11 & الثشاب & 60 & Young man \\
\hline 12 & الاضطر ابات & 55 & Unrest/disorder \\
\hline 13 & الفساد & 45 & Damage $\backslash$ Bad Thing \\
\hline
\end{tabular}

\section{Table 3: The Most Frequent Keywords Surrounding the Tunisian Revolution}

From the above table, we can observe that the three highest hits are related to essential individuals' names (social actors) who play an essential role in the Tunisian Revolution. They are the former President of Tunisia Ben Ali, Bouazizi and Tunisian opposition leader Rasheed Ghannouchi. ${ }^{2}$. On the other hand, another ten keywords from the list are associated with the detailed descriptions of the revolution event, which indicate how the news outlets depict the event in detail. Therefore, we can find many words related to 'protest', 'demonstration', 'authorities', 'violence', 'chaos', and many more.

\section{1. بن علي}

This critical keyword (nodal point ${ }^{3}$ ) which recorded the highest hit is referred to former Tunisian President Zain el-Bidine Ben Ali and most commonly known as Ben Ali. He becomes the President of Tunisia in 1987 and forced to step down during the Tunisian Revolution. Finally, Ben Ali has been forced to leave Tunisia on $14^{\text {th }}$ January 2011 . Thus, Ben Ali is the most important character in the Tunisian Revolution. Other keywords associated with Ben Ali are:

\begin{tabular}{|c|c|c|c|}
\hline No. & Keyword & Hit & Note \\
\hline 1 & الرئيس التونسي & 456 & President of Tunisia, Ben Ali's title. \\
\hline 2 & الحكومة التونسية & 385 & Tunisian Government. \\
\hline 3 & زين العابدين & 217 & Zain el-Bidine. \\
\hline 4 & 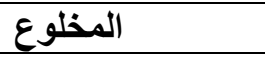 & 205 & Ousted \\
\hline 5 & ليلى & 59 & Laila Ben Ali - wife of Ben Ali \\
\hline
\end{tabular}

Table 4: The Associate Words Surrounding Keyword Ben Ali

\section{2. البوعزيزي}

The second important keyword based on the word frequent pertaining to the Tunisian Revolution is Mohamed el-Bouazizi. Being widely labelled as the most important man who sparks the Tunisian Revolution, he just an ordinary young man doing a small business in his hometown and suddenly gain huge public attention when he burns himself protesting the government. Therefore, other keywords that surround Bouazizi are associated with 'burn' and 'suicide' as follow:

\footnotetext{
2 Not to be confused with Ben Ali's long-serving Prime Minister and the Tunisian Prime Minister during the Revolution, Mohamed Ghannouchi.

${ }^{3}$ In short, the nodal point refers to the most important keywords that become the centre of other keywords. Other keywords work closely around the nodal point, making the nodal point the most important keyword in the corpus data.

Copyright $\odot$ GLOBAL ACADEMIC EXCELLENCE (M) SDN BHD - All rights reserved
} 
Volume 4 Issue 14 (June 2021) PP. 52-70 DOI 10.35631/IJHPL.414004

\begin{tabular}{|c|c|c|c|}
\hline Word & Hit & Word & Hit \\
\hline احراق & 26 & الاتتحار & 26 \\
\hline انتحار & 20 & حرق & 12 \\
\hline حرقًا & 12 & & \\
\hline
\end{tabular}

\section{3. الغنوشي}

The third most frequent keyword is Rasheed Ghannouchi, the most prominent opposition leader in Tunisia and the El-Nahda Movement leader, which carries a moderate Islamic approach. He formed the major opposition force to compete with Ben Ali's government and was punished with imprison. Hence, he lived in exile in the UK when the Revolution started. As many opposition leaders lived in exile outside Tunisia when the Revolution started, Ghannouchi and other oppositions only being mentions in the news when the protests widely separated all over Tunisia. Ghannouchi role becomes increasingly important when he returns to Tunisia slightly after Ben Ali left Tunisia. Thus, Besides Bouazizi, Ghannouchi also plays a vital role in the Tunisian Revolution, particularly in filling the political gap left by Ben Ali's regime.

\section{4. الاحتجاجات}

'Protests' is the highest frequency keyword used to describe the Tunisian Revolution events and how it takes place. The word الاحتجاجات(The protests) alone has recorded 151 hits. It also comes in different forms of nouns; singular, plural, definite word and indefinite word, as can be seen in the list below:

\begin{tabular}{|c|c|c|c|}
\hline Word & Hit & Word & Hit \\
\hline احتجاجًا & 70 & احتجاجات & 51 \\
\hline المحتجين & 40 & احتجاجية & 19 \\
\hline الاحتجاجية & 14 & المحتجون & 13 \\
\hline محتجين & 12 & الاحتجاج & 11 \\
\hline للاحتجاج & 9 & & \\
\hline
\end{tabular}

\section{5. المنظاهرين}

The word 'demonstrators' also recorded the highest hits after the word 'protests'. Although the word 'protests' come with many different forms and variants of nouns; singular, plural, definite word and indefinite word, the word 'demonstrators' recorded the highest number in term of associated forms. The 'demonstrators' has other 12 forms (word derivatives) in the corpus as follow:

\begin{tabular}{|c|c|c|c|}
\hline Word & Hit & Word & Hit \\
\hline المظاهرات & 41 & مظاهرة & 36 \\
\hline مظاهر ات & 34 & المتظاهرون & 26 \\
\hline متظاهرين & 24 & تَظْاهرَ & 16 \\
\hline تظاهرات & 15 & تظاهرة & 15 \\
\hline متظاهرون & 15 & المظاهرة & 13 \\
\hline ومتظاهرين & 13 & التظاهرات & 8 \\
\hline
\end{tabular}




\section{6. الثعب}

The keyword الثبع, which means the people, also comes in different variants (word derivatives) but still carry the same basic meaning. However, mostly it comes in the singular form as it is already referred to as plural in meaning.

\begin{tabular}{|l|l|l|l|}
\hline Word & Hit & Word & Hit \\
\hline شعبية & $\mathbf{9 8}$ & $\mathbf{4 9}$ \\
\cline { 1 - 4 } & $\mathbf{1 7}$ & \multicolumn{2}{|l}{} \\
\cline { 1 - 4 } & & &
\end{tabular}

\section{7. الثورة}

The other forms of the keyword of 'revolution' are:

\begin{tabular}{|l|l|l|l|}
\hline Word & Hit & Word & Hit \\
\hline$\ddot{3}$ & $\mathbf{5 9}$ & $\mathbf{1}$ & $\mathbf{1 5}$ \\
\hline
\end{tabular}

\section{8. السلطات}

The keyword of 'the authorities' only have one other form in the corpus, which in singular form السلطة (The authority). This singular word recorded 59 hits which are more than half compared to its plural form.

\section{9.}

Unemployment is the primary factor that leads to the Tunisian Revolution. The keyword 'unemployment' has another related word, mainly العاطلين (unemployed men). Unemployed men are mentioned in the corpus data eight times in the form of definite articles. It is worth noting that, during the early stage of protest, unemployed men were the majority of them.

\section{0. العنف}

The word 'violence' is mostly used to describe the revolution events, particularly those involving the clash between the demonstrators and the authorities. The word violence, in general, promotes negative connotation, which presupposes that the event was portrayed negatively. The word also has different forms in the corpus, from noun to adjective.

\begin{tabular}{|c|c|c|c|}
\hline Word & Hit & Word & Hit \\
\hline عنيفة & 35 & عنف & 17 \\
\hline العنيفة & 9 & & \\
\hline
\end{tabular}

\section{1. الشباب}

The other keyword الثشاب (Young man). They are the second group who participated in the protest since the early stage. Most of them were unemployed.

\begin{tabular}{|l|l|l|l|}
\hline Word & Hit & Word & Hit \\
\hline شاب & $\mathbf{4 3}$ & الشباب & $\mathbf{2 5}$ \\
\cline { 1 - 4 } & $\mathbf{2 2}$ & \multicolumn{2}{|l}{} \\
\cline { 1 - 4 } & &
\end{tabular}

\section{2. الاضطر ابات}

Similar to 'violence', the word chaos also promotes a negative impression, thus indicate a negative connotation on the protest event. This keyword also associated with another word, such as: 


\begin{tabular}{|c|c|c|c|}
\hline Word & Hit & Word & Hit \\
\hline الإضراب & 11 & إضراب & 11 \\
\hline اضطرابات & 10 & & \\
\hline
\end{tabular}

\section{3. الفساد}

In line with 'violence' and 'chaos, this keyword also promotes negative meanings. It only comes in the corpus data with another two types, which are:

\begin{tabular}{|l|l|l|l|}
\hline Word & Hit & Word & Hit \\
\hline بساد & $\mathbf{1 7}$ & $\mathbf{1 3}$ \\
\hline
\end{tabular}

14. Other Keywords

The other keywords which also recorded a significant number of hit are الشغب (chaos) 40 hits المتقلين , القتلى (dead people) 28 hits and 17 hits (remanded people) 28 hits and اشتباكات (clashes) 27 hits.

To sum up, most of the Tunisian Revolution keywords are centred around social actors and the prescriptive of the protest events. While the social actors cover both sides of the government and the antagonist, the keywords of social events mostly promote negative connotations.

\section{Wordlist Results on Egyptian Revolution}

Slightly different from wordlist results for the Tunisian Revolution, the corpus data on the Egyptian Revolution has 21 critical keywords that have the highest hit in word frequency. This is also in line with the fact that the corpus data pertaining to the Egyptian Revolution (ER) is much bigger than the TR. Moreover, the corpus data of ER cover a much more extended period compared to TR. As previously mentioned, these 21 keywords also come in different forms (derivatives) associated with every single of them, such as verb, noun, adjective, singular and plural. These 21 keywords are:

\begin{tabular}{|c|c|c|c|}
\hline No. & Keyword & Hit & Note \\
\hline 1 & مبارك & 2940 & Mubarak, Former Egyptian President. \\
\hline 2 & القاهرة & 803 & Cairo. \\
\hline 3 & التحرير & 792 & Tahrir Square. \\
\hline 4 & المتظاهرين & 733 & The Demonstrators \\
\hline 5 & الجيش & 716 & Army \\
\hline 6 & الشعب & 686 & People \\
\hline 7 & 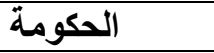 & 623 & Government \\
\hline 8 & النظام & 386 & Ruling System \\
\hline 9 & الاحتجاجات & 385 & The Protests \\
\hline 10 & السلطة & 350 & Authorities \\
\hline 11 & الثورة & 321 & Revolution \\
\hline 12 & الجمعة & 318 & Friday \\
\hline 13 & المصريين & 303 & Egyptian \\
\hline 14 & المعارضة & 292 & Opposition \\
\hline 15 & 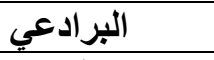 & 228 & El-Baradei, prominent Egyptian opposition leader \\
\hline 16 & الحوار & 183 & Dialogue \\
\hline 17 & 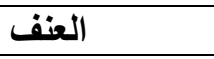 & 164 & Violence \\
\hline
\end{tabular}




\begin{tabular}{|c|c|c|c|}
\hline 18 & الثباب & 159 & Young man \\
\hline 19 & الايمقر اطية & 129 & Democracy \\
\hline 20 & إسرائيل & 126 & Israel \\
\hline 21 & اشتباكات & 73 & Clash \\
\hline
\end{tabular}

Table 5: The Most Frequent Keywords Surrounding the Egyptian Revolution

The data in the table shows that the keyword مبارك (Mubarak) the then Egyptian President recorded the highest hit compare to other keywords. This also reflects how Mubarak plays a vital role in the ER as he becomes the centre of attention in newspaper articles that report on the Egyptian Revolution. The same also applies to Ben Ali in the TR, as previously discussed. On the other hand, another two keywords from the list that recorded the highest hit are related to the ER's location, namely: the capital city of Egypt, Cairo and the Tahrir Square, in which the historic square is the centre location of the protest. El-Baradei is another essential keyword of the ER, as he is considered as the nemesis of Mubarak. He led the coalition of Egyptian oppositions and was intended to challenge Mubarak in the Egyptian Presidential Election before the Revolution. In addition, other keywords such as an army, 'demonstrators', 'revolution', 'violence', 'democracy' and many more are used to describe the revolution events that mostly take place in Cairo, particularly in Tahrir Square at the centre of Cairo city.

\section{1. مبارك}

This essential keyword in the Egyptian Revolution's corpus refers to Mohamed Hosni Mubarak, former Egyptian President who serves as Egyptian President from 1981 until 2011. Mubarak is the centre of attention in the Egyptian Revolution when the Egyptian protested against his government and asked him to resign. Finally, on $11^{\text {th }}$ February 2011, Mubarak declared his resignation after serving as President of his country for almost 30 years. The keyword مبارك also primarily associated with another keyword which recorded among the highest hit according to the wordlist result. These words are:

\begin{tabular}{|c|c|c|c|}
\hline No. & Keyword & Hit & Note \\
\hline 1 & الرئيس المصري & 1775 & President of Egypt. \\
\hline 2 & الجمهورية المصرية & 1007 & Egyptian Government. \\
\hline 3 & حسني & 687 & Hosni (Mubarak). \\
\hline 4 & رئيس & 505 & President \\
\hline 5 & عمر سليمان & 431 & Omar Suleiman - former Vice President of Egypt \\
\hline 6 & ل للرئيس & 135 & For the President \\
\hline 7 & 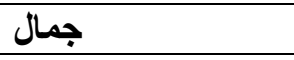 & 122 & Jamal Mubarak - the son of Mubarak \\
\hline 8 & لمبارك & 116 & For Mubarak \\
\hline 9 & 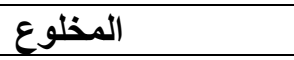 & 74 & Ousted \\
\hline 10 & سوزان & 66 & Suzan Mubarak - Wife of Mubarak. \\
\hline
\end{tabular}

Table 6: The Associate Words Surrounding Keyword Ben Ali

2. القاهرة

This keyword refers to the capital city of Egypt, Cairo. Cairo is the central location for the Egyptian Revolution besides other Egyptian cities such as Mansoura, Alexandra and Tanta. Cairo also gains huge international attention during the Revolution. Another keyword associated with 'Cairo' is العاصمة(the capital city), which recorded 141 hits. 
3. التحرير

This third keyword is closely related to the previous keyword, 'Cairo'. Tahrir Square situated in the middle of Cairo, and it is considered an essential landmark of Cairo. During the Revolution, thousands of Egyptians gathered here to show their protest toward Mubarak' regime. Another keyword that closely works with 'Tahrir Square' is ميدان (square) 745 hits.

\section{4. المتظاهرين}

This keyword means the demonstrators. It is widely used to describe people who participated in the Revolution, particularly those gathered in Tahrir Square. It also comes in many language forms such as noun, verb, singular and plural, as can be seen in the following table:

\begin{tabular}{|c|c|c|c|}
\hline Word & Hit & Word & Hit \\
\hline المتظاهرون & 233 & المظاهرات & 226 \\
\hline مظاهرات & 135 & التظاهرات & 104 \\
\hline تظاهرات & 73 & التظاهز & 61 \\
\hline مظاهرة & 50 & تَظظاهزَ & 42 \\
\hline تظاهرة & 41 & للمتظاهرين & 40 \\
\hline متظاهرين & 38 & متظاهرون & 37 \\
\hline المظاهرة & 34 & & \\
\hline
\end{tabular}

5. الجيش

This keyword means 'army'. In contrast to the 'demonstrator' keyword, it is widely used to refer to the group that control the demonstrators to protect the government and other public interests. Therefore, there is a lot of clash between these two groups of demonstrators and the Army during the Revolution. There is also keyword of الثرطة (police) with 329 hits and 49 hits for شرطة. Police also help the Army control the demonstrators, and when the demonstration becomes violence, the armed force takes full charge in dealing with the demonstrators. Another keyword that also used to refer the Army العسكرية 160 hits and 220 hits, العسكري hits.

6. الشعب

Other language forms for this keyword in the corpus which recorded a significant number of hits are:

\begin{tabular}{|c|c|c|c|}
\hline Word & Hit & Word & Hit \\
\hline الثعبية & 147 & للشعب & 64 \\
\hline شعبية & 56 & & \\
\hline
\end{tabular}

\section{7. الحكومة}

The keyword 'government' also forms the opposite image to compete with the 'demonstrators'. In addition, the government also tries to protect their interests and retake the actions of the demonstrators. Simultaneously, the government has been negatively labelled by the demonstrators to show their anger and protest towards the ruling system. Other language forms for this keyword are:

\begin{tabular}{|l|l|l|l|}
\hline Word & Hit & Word & Hit \\
\hline حكومة & $\mathbf{2 3 4}$ & $\mathbf{5 0}$ & $\mathbf{5 0}$ \\
\hline
\end{tabular}


8. النظام

This keyword means the 'ruling system', and it is closely related to 'government'. According to wordlist result from the corpus, other language forms for this keyword are:

\begin{tabular}{|c|c|c|c|}
\hline Word & Hit & Word & Hit \\
\hline نظام & 241 & التنظيم & 49 \\
\hline تنظيم & 47 & نظامهُ & 47 \\
\hline للنظام & 43 & & \\
\hline
\end{tabular}

9. الاحتجاجات

Other language forms for this keyword are:

\begin{tabular}{|c|c|c|c|}
\hline Word & Hit & Word & Hit \\
\hline المحتجون & 90 & احتجاجات & 79 \\
\hline الاحتجاج & 45 & & \\
\hline
\end{tabular}

10. السلطة

This is another keyword that has a direct link with the keyword of 'government'. It also comes in different language form, as can be seen in the following table:

\begin{tabular}{|l|l|l|l|}
\hline Word & Hit & Word & Hit \\
\cline { 1 - 2 } & $\mathbf{1 7 8}$ & للسطلة & $\mathbf{1 2 8}$ \\
\cline { 1 - 3 } & $\mathbf{3 7}$ & &
\end{tabular}

\section{1. الثورة}

This keyword which means 'revolution', comes with another two language forms. They are:

\begin{tabular}{|l|l|l|l|}
\hline Word & Hit & Word & Hit \\
\hline$\ddot{3}$ & $\mathbf{1 3 2}$ & $\ddot{\mathbf{H}}$ & $\mathbf{4 3}$ \\
\hline
\end{tabular}

\section{2. الجمعة}

The Egyptian Revolution is well known for its link with Friday. Friday is the day when the demonstrators hold their mass protest in Tahrir Square and other Egyptian cities. The protests mostly started after the Friday Prayers, which began with speeches and sermons, encouraging the protestors to continue their protest until they achieved their 'noble aim'. The demonstrators also set Friday as the final day for Mubarak to resign or another significant uprising stage. Therefore 'Friday' is among important keyword which recorded a significant number of hit from the corpus. Another language form for this keyword is جمعةwith 120 hits.

\section{3. المصريين}

This keyword refers to the prominent participants in the Egyptian Revolution. Rather than being label as 'demonstrator', they are more generally labelled as 'Egyptian'. Another word which also carries almost similar meaning is المواطنين (residents) 128 hits. Other language forms for the keyword 'Egyptian' are:

\begin{tabular}{|l|l|l|l|}
\hline Word & Hit & Word & Hit \\
\cline { 1 - 4 } & $\mathbf{9 2}$ & $\mathbf{7 7}$ & \\
\cline { 1 - 4 } & $\mathbf{7 4}$ & &
\end{tabular}


Naturally, this keyword represents an opposite wave with the keyword 'government'. Other language forms for this keyword are:

\begin{tabular}{|c|c|c|c|}
\hline Word & Hit & Word & Hit \\
\hline المعارض & 64 & معارضة & 43 \\
\hline المعارضين & 35 & & \\
\hline
\end{tabular}

It is also good to mention that the most prominent Egyptian opposition movement 'the Muslim الإخوان Brotherhood' also recorded a significant number of hit from the corpus, which is 183 for and another 94 hits for الاخوان.

15. البرادعي

Mohamed El-Baradei is a well-known figure for his international involvement in International Atomic Energy Agency (IAEA) and won the Noble Peace Prize in 2005. He then competes with Mubarak in the Egyptian Presidential election. During the Revolution, he played an essential role with other opposition movements to topple the Mubarak regime.

16. الحوار

This keyword perhaps shows that the Revolution is not always riots, chaos and violence. There is some initiative from the government and the opposition toward a peaceful end of the Revolution. One of this initiative is through dialogue or negotiation among the leaders.

\section{7. العنف}

This keyword does not have any other language form in the studied corpus other than the indefinite word.

$$
\text { 18. الثباب }
$$

Youth is the prominent participants in the Revolution. Word شباب also recorded 82 hits.

\section{9. الايمقراطية}

One of the significant demands the demonstrators ask during the Revolution is to have their right to 'real democracy'; therefore, the keyword 'democracy' recorded a high number of hit in the wordlist result. Other language forms associated with this keyword are:

\begin{tabular}{|l|l|l|l|}
\hline Word & Hit & Word & Hit \\
\hline الديمقراطية & $\mathbf{7 8}$ & $\mathbf{6 3}$ \\
\hline
\end{tabular}

Democracy also associated with the election; thus, we can find the word انتخابات التات almost the same number with keyword 'democracy' 130 hits plus الانتخاباتwith 115 hits.

20. إسرائيل

It is quite interesting to mention that the Egyptian Revolution has grabbed attention and pressure from foreign countries, particularly Israel and the United States of America (USA). According to the wordlist result, the word 'Israel' is mentioned 221 times in the corpus and the USA with 425 hits. The details as follow: 


\begin{tabular}{|c|c|c|c|}
\hline Word & Hit & Word & Hit \\
\hline إسر ائيل & 126 & الاسر ائيلي & 51 \\
\hline إسر ائيل & 44 & & \\
\hline
\end{tabular}

\begin{tabular}{|c|c|c|c|}
\hline Word & Hit & Word & Hit \\
\hline الأمريكية & 98 & الأمريكي & 78 \\
\hline الأميريكية & 74 & الأميريكي & 66 \\
\hline الأميركية & 65 & الامريكي & 44 \\
\hline
\end{tabular}

It is worth to mention that other words that associated with the USA, particularly their leaders, the name also recorded a high number of hit for instance: واشنطن (Washington) 118 hits, بارأك (Barack) 106 hits, الأبيض (White House) 84 hits, أوباما (Obama) 67 hits and Clinton 66 كلينتون hits.

\section{1. شتباكات}

The other language form for this keyword is الاشتباكات which recorded 59 hits.

22. Another keyword.

According to the wordlist result produced by Antconc software from the studied corpus, other significant important keywords are الغضب (anger) 104 hits, الفساد (damage) 91 hits, 51 hits for each of this word which refers to the action taken toward the demonstrators القتلى (killed), الاضطرابات (arrested) and القبض (remanded), المعتلين (prisoners). In addition, word (unrest/disorder) only recorded quite a low number of hits in the corpus of Egyptian Revolution with 45 hits compared to other keywords. Most of these keywords are used to portray the event. Similar to the TR, these keywords, in general, carry negative connotations. Hence it is presupposed that the event was portrayed negatively in the news articles.

\section{Comparing and Contrasting the Wordlist Results}

Before going into the details of the comparison between both set of corpus data, we must acknowledge that both corpus data for Tunisian revolution TR and Egyptian revolution ER have different size and cover the different length of time. The corpus data for the Egyptian Revolution is more significant than the Tunisian Revolution in term of both the total number of articles and the total number of words. Corpus for ER has 399 articles and 232,176 number of words compared to 159 articles and 73,331 words for TR. Therefore, the corpus data on ER has recorded a higher number of hit for each of its keyword compare to the corpus data on TR. In addition, the ER corpus offers more keywords and the language variants associated with every keyword. Although both corpus data for the ER and the TR come from three same modern Arabic newspaper institutions, the number of articles published by them is more towards the Egyptian than the Tunisian Revolution. This shows that the ER has grabbed more attention among the Arabic media compare to the TR.

Despite these fundamental differences between both corpus data, the wordlist results produced by Antconc software reveal that both of the corpora share many similarities. The first and the most apparent similarities between the corpus of the Egyptian Revolution and the Tunisian Revolution is both former Egyptian and Tunisian presidents during the Revolution have recorded the highest hit in the wordlist result. This result reflects how important these two individuals in the discourse of the Egyptian and Tunisian Revolution. It is also safe to say that Mubarak and Ben Ali are the centre of attention for each Egyptian and Tunisian Revolution. 


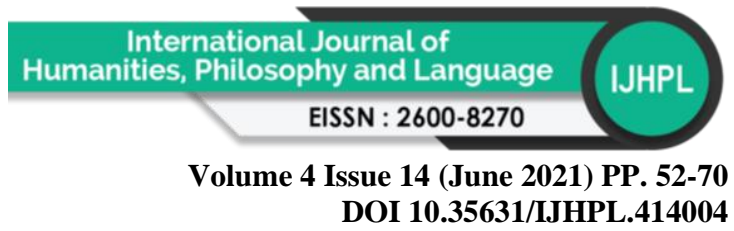

Furthermore, both Mubarak and Ben Ali keywords are associated with many other words linked to their position as the President of their countries. Interestingly, Mubarak and Ben Ali's keywords also associated with their wives Susan Mubarak and Laila Ben Ali. Finally, both keywords of Mubarak and Ben Ali also shared the most high frequency of adjective associated with their name, which is المخلوع (Ousted).

Both corpus of Egyptian and Tunisian Revolution wordlist result also reveals that they share

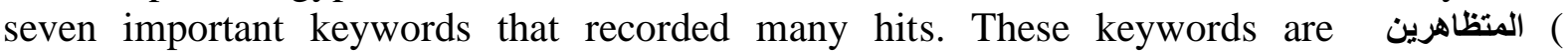
demonstrators), الاحتجاج (protest), السلطة (authority), الثبع (people), الثورة (Revolution), العنف (violence) and الثباب (youth). All these keywords are used to describe the details of revolution events for both Egyptian and Tunisian revolutions. Although there are a group of words such as القتلى (killed), المعتقلين (people being arrested), الفسادرابات (bad/damage) and (unrest/disorder) recorded a low number of hit for both sets of corpus data, all these words are widely being used to describe the revolution events in both corpus data. Again, most of these keywords carry negative connotations. Hence the events described in the corpus data are cast under a negative light.

In terms of differences between the corpus of the Egyptian Revolution and the Tunisian Revolution's corpus, the wordlist results show that each of these two revolutions has its unique characters. For example, while the Egyptian Revolution is famously related to keywords of location such as 'Cairo' and 'Tahrir Square', the Tunisian Revolution, however, is closely linked to names of an important individual who spark the wave of Revolution like 'Bouazizi' and 'ElGhannouchi'. Not much indication was recorded in term of the geographical location of protest events in TR except a brief mention of Sidi Bouzid, the birthplace of the Arab Spring and the City of Tunis, the capital city of Tunisia.

Among other unique features in term of keywords for the Egyptian Revolution is the high frequency of the keyword 'Friday' which cannot be found in the corpus of the Tunisian Revolution TR. Furthermore, we can observe a significant number of foreign countries involved in the news articles around the Egyptian Revolution, particularly from the USA and Israel, which is not the same case surrounding the news coverage of TR. Therefore, the total number of hit for all word associated with both keywords of USA and Israel in the frequency list is 425 and 221, respectively. This reflects the international attention that has been given to the Revolution that happened in Egypt compared to Tunisia.

One of the primary reasons for mass protest among Tunisian during their Revolution is unemployment issues. Thus, the word البطالة 'unemployment' has recorded a high number of hit in the frequency list of Tunisian revolution corpus. In contrast, unemployment is not considered a significant issue in the Egyptian Revolution. As a result, the word البطالة 'unemployment' does not record a high number of hit in Egyptian corpus. Egyptian in their Revolution asks for 'real democracy' and 'clean election'. This can be observed from the wordlist result for the Egyptian Revolution, which shows both keywords of الايمقراطية (democracy) and انتخابات(election) have recorded a high number of frequencies.

Moreover, the ER indicates a severe involvement of the Egyptian Arm Force, which significantly influences Egypt's political and social life. The same does not apply in TR, in which the Tunisian Army opted to be impartial during the crisis, hence limit their involvement in the clash. Besides, there is the direct involvement of Egyptian oppositions since the early 
Volume 4 Issue 14 (June 2021) PP. 52-70

DOI 10.35631/IJHPL.414004

stage of the protest compared to the TR. This is mainly because the Egyptian opposition was allowed to exist in Egypt (despite many of their leaders have been detained), while there is a severe absence of 'real' opposition in Tunisia during Ben Ali's era. Hence, Tunisian oppositions only involved in the event after Ben Ali left the country.

To sum up, the wordlist result shows that both corpus data on the Egyptian Revolution and the Tunisian Revolution of Arab Spring have their own keyword, which in turn reflects the unique characters of each Revolution. However, there is a lot of command keyword associated with both versions of revolutions. These keywords are mainly related to the details of revolutions events themselves.

\section{Conclusion}

The so-called Arab Spring, which began in late 2010, has brought a significant transformation to the social and political landscape of the Arab region. As one of the most effective tools in shaping people's perspective, the media has comprehensively reported the event since the beginning. However, the media has been covering the event with an attitude that makes the narrative of the event significantly differ from each news institution.

This study highlighted one of the main linguistics elements of the modern standard Arabic news discourse construction surrounding the Arab Spring. By focusing on the two versions of the Arab Spring, namely the Tunisian and the Egyptian Revolution, the study has highlighted the most prominent keywords in the corpus data surrounding the two revolutions. The results also emphasised the previous findings in many pass literatures on the so-called the Arab Spring. It is showed that the news outlets covered the historical event with an attitude. This is done by highlighting certain keyword and marginalising other. It also reflect the outlet's stance toward the event and the social actors participated in the revolution.

The results showed many shared keywords between the two revolutions, such as command words related to the protests, demonstration, authority and governments, which indicated the shared similarities in the ingredient of the two revolutions. However, looking into more details of the keywords showed that the wordlist result shows that both corpus data on the Egyptian Revolution and Tunisian Revolution of Arab Spring have their own keywords, reflecting the unique characters of each Revolution. This further emphasised the different characters of each Revolution and significantly different events in these two revolutions. These significantly differed keywords have abolished the command shared keywords associated with both versions of revolutions, hence highlighted the distinguished identity of each Revolution. These keywords, moreover, are mainly related to the details of revolutions events themselves, which in turn make each of these two Revolution is unique by itself.

\section{References}

Baker, P., \& McEnery, T. (2005). A corpus-based approach to discourses of refugees and asylum seekers in UN and newspaper texts. Language and Politics, 4(2), 197-226.

Blommaert, J. (2005). Discourse: A Critical Introduction. Cambridge: Cambridge University Press.

Chilton, P. (2005). Missing Links in Mainstream CDA: Modules, Blends and the Critical Instinct in P. Chilton \& R. Wodak. (Eds.), A New Agenda in (Critical) Discourse Analysis: Theory, Methodology and Interdisciplinarity Amsterdam: John Benjamins. 


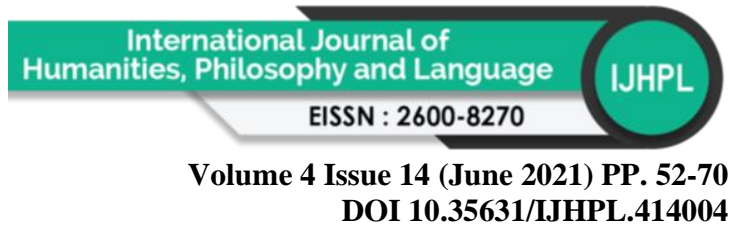

Chilton, P., \& Schaffner, C. (2002). Introduction: Themes and principles in the analysis of political discourse In P. Chilton \& C. Schaffner (Eds.), Politics as Text and Talk: Analytic Approaches to Political Discourse (pp. 1-41). Amsterdam: J. Benjamins.

Chouliaraki, L., \& Fairclough, N. (1999). Discourse in Late Modernity. Edinburgh: Edinburgh University Press.

Fairclough, N. (1988). Discourse representation in media discourse. Sociolinguistics, 17, 125139.

Fairclough, N. (1989/2001). Language and Power (2nd ed.). London: Longman.

Fairclough, N. (1992). Discourse and Social Change. Cambridge: Polity Press.

Fairclough, N. (1993). Critical discourse analysis and the marketisation of public discourse: The universities. Discourse and Society, 4(2), 133-168.

Fairclough, N. (1995a). Critical Discourse Analysis: The Critical Study of Language. London: Longman.

Fairclough, N. (1995b). Media Discourse. London: Hodder Arnold.

Fairclough, N. (2000). New Labour, New Language? London: Routledge.

Fairclough, N. (2001/1989). Language and Power (2nd ed.). London: Longman.

Fairclough, N. (2003). Analysing Discourse: Textual Analysis for Social Research. London:

Routledge.

Fairclough, N. (2006). Language and globalisation. London: Routledge.

Fairclough, N., Wodak, R., \& Mulderrig, J. (2011). Critical discourse analysis. In T. van Dijk (Ed.), Discourse Studies: A Multidisciplinary Introduction (2nd ed., pp. 357-378). London: Sage.

Foucault, M. (1972). The Archaeology of Knowledge. London: Tavistock Publications.

Fowler, R. (1991). Language in the News: Discourse and Ideology in the Press. London:

Routledge.

Fowler, R, Hodge, B., Kress, G., \& Trew, T. (1979). Language and Control. London: Routledge.

Franklin, B., Hamer, M., Hanna, M., Kinsey, M., \& Richardson, J. (2005). Key Concepts in Journalism Studies. London: Sage.

Harun, F, Ismail, M et al. (2019), 'The Driving Restriction on Saudi Women: Critical Analysis of Modality in Arabic Online News Discourse', Journal of Fatwa Management and Research (2019): 466-87.

Harun, F and Ismail, M. (2020) 'Saudi Women Participation in Sports: Critical Analysis of Presupposition Strategies in Arabic Online News Discourse', Journal Sains Insani (Vol. 5, 2020): 134-50.

Ismail, M., Harun, F., Daoudi, A. (2018). Naming Strategies in Modern Standard Arabic Online News Discourse: The Case of Al-Jazeera And BBC Coverage on the 2011 Tunisian Jasmine Revolution in Journal of Global Business and Social Entrepreneurship (GBSE) Vol. 4: No. 11 (May 2018) page 158-171.

Ismail, M. (2019). Aljazeera Arabic and BBC Arabic Online News Coverage of the 2011 Arab Spring in Tunisia and Egypt: Critical Discourse Analysis. PhD Thesis. The University of Birmingham. The UK.

Ismail, M and Harun, F. (2021) Modern Standard Arabic Online News Discourse of Men and Women: Corpus-Based Analysis. Asian Journal of Behavioural Sciences, [S.1.], v. 3, n. 1, p. 24-39, Mar. 2021: p134-50.

Laclau, E and Mouffe, C. (1985). Hegemony and Socialist Strategy. London: Verso.

Reisigl, M and Wodak, R. (2001). Discourse and Discrimination: Rhetoric of Racism and Antisemitism. London: Routledge. 
Volume 4 Issue 14 (June 2021) PP. 52-70 DOI 10.35631/IJHPL.414004

Richardson, J. (2007). Analysing Newspapers: An Approach from Critical Discourse Analysis. New York: Palgrave Macmillan 